\title{
Parathyroid Clear Cell Hyperplasia
}

National Cancer Institute

\section{Source}

National Cancer Institute. Parathyroid Clear Cell Hyperplasia. NCI Thesaurus. Code C6033.

A hyperplasia of the clear cells of the parathyroid gland. 